\title{
PENGELOLAAN KELAS DALAM PEMBELAJARAN BAHASA JEPANG OLEH GURU BAHASA JEPANG SMA NEGERI 2 SINGARAJA
}

\author{
P. R. Riadi ${ }^{1}$, I. W. Sadyana ${ }^{2}$, dan D. M. S. Mardani ${ }^{3}$ \\ Program Studi Pendidikan Bahasa Jepang, \\ Universitas Pendidikan Ganesha \\ Singaraja, Bali \\ e-mail: riyan.riadi@rocketmail.com \\ desakmardani@undiksha.ac.id wayan.sadyana@undiksha.ac.id
}

\begin{abstract}
Abstrak
Penelitian ini bertujuan untuk mendeskripsikan bagaimana pengelolaan kelas yang dilakukan oleh guru bahasa Jepang dalam pembelajaran bahasa Jepang di SMA Negeri 2 Singaraja. Pengumpulan data dilakukan dengan metode observasi, dokumentasi, dan wawancara. Dianalisis menggunakan metode deskriptif kualitatif. Hasil penelitian menunjukkan pengelolaan kelas yang efektif merupakan persyaratan mutlak terwujudnya pembelajaran yang efektif dan optimal. Keterampilan guru dalam mengelola kelas secara signifikan memengaruhi situasi dan kondisi pembelajaran di dalam kelas. Dalam mengelola kelas guru menggunakan berbagai pendekatan, prinsip-prinsip, dan komponenkomponen pengelolaan kelas untuk menciptakan dan memelihara kondisi belajar yang optimal. Pendekatan resep (cook book), keluwesan, penekanan pada hal-hal yang positif, dan menemukan serta memecahkan tingkah laku yang menimbulkan masalah tidak dilakukan oleh guru. Penataan ruang kelas dilakukan guru dengan cara disesuaikan dengan pembelajaran dan/atau atas seizin dari sekolah.
\end{abstract}

Kata kunci: Pendekatan, prinsip, komponen, penataan ruang kelas

要旨

本研究の目的はシンガラジャー第二国立高校において日本語を教えるための対策に関して日本語教師 により書き表す。データは観察や文書化やインタビューにより収集しそれを定性的記述法により分析 した。調査結果は効果的な授業を行われるためは効果的最適に授業の管理するのは一つの条件だ。教 師の実力によるの有意に授業の管理するのは効果的な授業を影響すると分かった。授業を管理するた め教師は効果的な授業を行われるよう様々な対策や要素や法を行われた。アプローチ秘方「クックブ ック」、社交的、積極的な圧力やまたは教師は問題を起こすような行為しないこと分かった。本学の 許可と授業を適当な管理を行うによる教師は授業を行われる。

キーワード : アプローチ、法、要素、授業の管理

\section{Pendahuluan}

Pada dasarnya dalam proses pembelajaran di kelas, keterampilan guru merupakan salah satu faktor yang penting dalam menentukan keberhasilan peserta didik. Oleh karena itu, guru yang kompeten akan lebih mampu menciptakan lingkungan belajar yang efektif dan lebih mampu mengelola kelas, sehingga tujuan pembelajaran dapat tercapai. Tentunya dalam pelaksa-naan pembelajaran guru berpatokan pada kurikulum yang berlaku, baik itu kurikulum tingkat satuan pendidikan (KTSP) atau kurikulum 2013. Kurikulum satuan pendidikan diterapkan oleh lembaga pendidikan sebelum diberlakukannya kurikulum 2013. Setelah diberlakukannya kurikulum 2013, lembaga pendidikan serta penyelenggara pendidikan mulai menerapkan kurikulum 2013 sebagai pengganti kurikulum tingkat satuan pendidikan. Dalam para-digma perubahan kurikulum tentu saja akan membawa konsekuensi perubahan cara guru dalam mengajar. Perubahan cara mengajar guru akan dapat memengaruhi pengelolaan kelas yang dilakukan guru.

Menurut UU RI Nomor 14 Tahun 2005 (dalam Barnawi \& Arifin 2012:201) guru merupakan pendidik profesional yang tugas utamanya berat, yaitu mendidik, mengajar, membimbing, mengarahkan, melatih, menilai, dan mengevaluasi peserta didik pada 
pendidikan anak usia dini jalur pendidikan formal, pendidikan dasar, dan pendidikan menengah. Untuk itu sebagai agen pembelajar selain profesional guru juga harus memiliki abilitas. Abilitas merupakan faktor penting dalam menentukan kualitas pekerjaan. Menurut Barnawi \& Arifin (2012:201) "Abilitas erat kaitanya dengan pengetahuan dan keterampilan yang dimiliki individu". Abilitas dapat dipandang sebagai suatu karakteristik umum dari seseorang yang berhubungan dengan pengetahuan dan keterampi-lan yang diwujudkan melalui tindakan. Direktorat Tenaga Kepen-didikan (dalam Barnawi \& Arifin 2012:201) menyatakan secara aplikatif, abilitas seorang guru dapat terindikasi melalui delapan keterampilan mengajar.

Salah satu dari delapan keterampilan mengajar guru adalah keterampilan manajemen kelas atau pengelolaan kelas. Menurut Djamarah \& Zain (2006:173) "penge-lolaan kelas adalah keterampilan guru untuk menciptakan dan memelihara kondisi belajar yang optimal dan mengembalikannya bila terjadi gangguan dalam proses belajar mengajar". Menurut Sudir-man (dalam Fathurrohman \& Sutikno 2011:104) pengelolaan kelas merupakan penyediaan fasilitas bagi bermacam-macam kegiatan belajar siswa yang berlangsung pada lingkungan sosial, emosional, dan intelektual anak dalam kelas menjadi sebuah lingkungan belajar yang membelajarkan. Fasilitas yang disediakan itu memungkinkan siswa belajar dan bekerja, tercapainya suasana kelas yang memberikan kepuasan, suasana disiplin, nyaman, dan penuh semangat. Sehingga terjadi perkembangan intelektual, emosional, dan sikap serta apresiasi pada siswa.

Berdasarkan pendapat para ahli yang telah disebutkan, dapat disimpulkan bahwa manajemen kelas atau pengelolaan kelas adalah keterampilan guru untuk mencipta-kan dan memelihara kondisi belajar yang optimal, positif, dan mem-fasilitasi kegiatan pembelajaran sesuai kebutuhan agar peserta didik dapat belajar secara efektif dan efisien. Sehingga terjadi per-kembangan intelektual, emosional, dan sikap siswa guna mencapai tujuan pembelajaran.

Dalam pengelolaan kelas, mengelola perbedaan-perbedaan kekuatan individual untuk menjadi sebuah aktivitas belajar bersama tentu tidak mudah bagi guru. Di kelas segala aspek pendidikan pengajaran bertemu dan berproses. Guru dengan segala kemampuannya, peserta didik dengan segala latar belakang dan sifat-sifat individualnya, kurikulum dengan segala komponen-nya, dan materi serta sumber pelajaran dengan segala pokok bahasannya bersatu padu dan berinteraksi di kelas.

Sebagai seorang guru masalah pokok yang dihadapi baik yang pemula maupun yang sudah berpengalaman adalah pengelolaan kelas. Djamarah \& Zain (2006:173) menyatakan "aspek yang paling sering didiskusikan oleh penulis profesional dan oleh para pengajar adalah pengelolaan kelas". Ini dikarenakan pengelolaan kelas merupakan masalah tingkah laku yang kompleks dan guru meng-gunakannya untuk men-ciptakan dan mempertahankan kondisi kelas. Tugas utama dan paling sulit bagi guru adalah pengelolaan kelas, apalagi tidak ada pendekatan yang dikatakan paling baik. Hal ini sejalan dengan pendapat Arikunto (1993:191) yang menyatakan me-ngelola kelas bukan merupakan tugas yang ringan, guru perlu banyak belajar sebelum memulai tugas profesinya.

Dengan demikian pengelolaan kelas yang efektif merupakan persyaratan mutlak bagi terjadinya proses pembelajaran yang efektif. Untuk itu dalam menjalankan tugas dan kewajiban sebagai seorang pendidik, menguasai keterampilan pengelolaan kelas adalah hal yang penting agar proses pembelajaran berjalan dengan efektif dan tujuan pembelajaran dapat tercapai.

Guru yang tidak dapat menguasai keterampilan pengelola-an kelas dengan baik akan kesulitan dalam menangani berbagai tingkah laku siswa yang menimbulkan masalah, kesulitan dalam menyikapi perbedaan latar belakang dan karakter dari masing-masing individu yang berbeda-beda. Serta kesulitan mengelola berbagai aspek pem-belajaran menjadi kegiatan belajar bersama, dan kesulitan menciptakan dan memelihara lingkungan belajar yang kondusif, nyaman dan menyenangkan. Hal tersebut akan dapat membuat pembelajaran tidak berjalan dengan efektif dan tujuan pembelajaran tidak dapat tercapai.

Guru yang tidak dapat menangani berbagai permasalahan yang muncul di dalam kelas juga akan berdampak pada guru itu sendiri sebagai pendidik. Guru akan menjadi malas 
mengajar bahkan tidak datang ke dalam kelas untuk mengajar jika terdapat siswa yang nakal atau kondisi kelas tertentu berantakan dan bermasalah. Se- baliknya guru yang terampil dalam mengelola kelas akan selalu bersemangat untuk mengajar dan selalu siap menghadapi berbagai permasalahan yang muncul ketika proses pembelajaran.

Penelitian mengenai pengelolaan kelas pernah dilakukan oleh Surjana (2002) melakukan penelitian tentang efektivitas pengelolaan kelas. Hasil penelitian ini menunjukan bahwa (1) kontribusi motivasi kerja guru terhadap efektivitas pengelolaan kelas, yaitu mengkondisikan kelas dengan pendekatan memodifikasi perilaku, memfasilitasi iklim sosioemosional, dan memfasilitasi proses dinamika, masih belum optimal, hanya $37,70 \%$. (2) Kontribusi gaya kepemimpinan guru terhadap efektivitas pengelolaan kelas, juga masih belum optimal $(43,10 \%)$, meskipun sedikit lebih tinggi dari kontribusi motivasi kerja. (3) Secara bersama-sama kontribusi motivasi kerja dan gaya kepemimpinan guruguru SMU Kristen BPK Penabur di Jakarta juga masih belum optimal (42,80\%).

Penelitian lain mengenai pengelolaan kelas dilakukan oleh Mardhiah, Eliwatis., dan Khaira (2014) melakukan penelitian tentang pelaksanaan pengelolaan kelas oleh guru biologi dalam menciptakan dan memelihara kondisi belajar yang optimal. Hasil penelitian ini menunjukan bahwa guru biologi di SMPN 2 Sungayang telah mampu melaksanakan pengelolaan kelas dengan baik dalam menciptakan dan memelihara kondisi belajar yang optimal. Namun kadang hal tersebut sering terkendala karena kurangnya rasa kedisplinan dari siswa. Misalnya siswa sering terlambat masuk ke dalam kelas, sehingga waktu untuk belajar menjadi berkurang, akibatnya tujuan pembelajaran sering tidak tercapai.

Penelitian mengenai pe-ngelolaan kelas juga pernah dilakukan oleh Ulandari (2015). Hasil penelitian menunjukan bahwa pengelolaan kelas telah dilaksanakan dengan cukup baik yaitu guru bahasa Jepang SMA N 1 Sukasada diawal pelajaran mengatur waktu dengan membagi waktu pembelajaran secara sistematis saat memulai pembelajaran, penyajian materi, latihan, penugasan, dan penutup. Dalam mengelola perilaku siswa, guru SMA N 1 Sukasada meminta siswa mencari tempat duduk yang kosong dan memasukkan buku saat tes mendengarkan. Guru me-lakukannya untuk memberikan motivasi kepada siswa agar berlaku jujur dan percaya dengan kemampuan sendiri. Dalam men-jelaskan dan melatih pola kalimat, guru menggunakan media gambar agar lebih menarik. Pembahasan pada penelitian ini sebatas tentang pengelolaan waktu dan kelas, pengelolaan perilaku siswa, dan pengelolaan strategi guru.

Oleh sebab itu, dilakukan penelitian pengelolaan kelas lebih lanjut dengan lebih menekankan mengenai pendekatan dalam pengelolaan kelas, prinsip-prinsip pengelolaan kelas, komponen-komponen keterampilan pengelolaan kelas, dan penataan ruang kelas yang dilakukan guru. Penelitian ini dilakukan di SMA Negeri 2 Singaraja dengan guru bahasa Jepang SMA Negeri 2 Singaraja sebagai subjek penelitian. SMA Negeri 2 Singaraja dipilih sebagai tempat melakukan penelitian karena SMA N 2 Singaraja merupakan SMA Negeri yang mengalami perubahan kurikulum dari menerapkan KTSP menjadi kurikulum 2013. Perubahan kurikulum tentu saja akan me-mengaruhi pengelolaan kelas yang dilakukan oleh guru. Karena disamping belajar menggunakan/ menerapkan kurikulum terbaru, guru juga harus tetap mengelola kelas dalam menjalankan tugas profesinya yaitu mengajar.

Di SMA N 2 Singaraja terdapat guru bahasa Jepang yang merupakan lulusan dari pendidikan bahasa Jepang dan hal ini juga yang membedakan dengan guru di SMA lain yang sebagian besar belum tentu memiliki latar belakang pendidikan dari pendidikan bahasa Jepang. Serta guru bahasa Jepang SMA N 2 Singaraja sudah memenuhi kualifikasi akademik guru. Dalam peraturan menteri pendidikan nasional RI nomor 16 tahun 2007 tentang Standar Kompetensi Akademik dan Kompetensi Guru, dinyatakan bahwa kualifikasi akademik guru SD/MI, SMP/MTs, dan SMA/MA minimum diploma empat (D-4) atau sarjana (S1).

Selain itu, berdasarkan hasil observasi yang telah dilakukan pada tanggal 22 Agustus 2016, guru bahasa Jepang SMA N 2 Singaraja terlihat cukup terampil dalam mengendalikan jalannya pem-belajaran dan mengendalikan tingkah laku siswa yang meng-ganggu jalannya proses pembelaja-ran. Selama pembelajaran ber-langsung guru terlihat bersemangat dan siap menggunakan berbagai materi/bahan/media dalam mengajar. Serta guru terlihat 
merespon baik berupa kata-kata maupun tindakan berbagai tingkah laku siswa yang dianggap mengganggu jalannya proses pembelajaran. Dalam merespon berbagai tingkah laku siswa tersebut, guru tidak terlihat menunjukkan sikap/perilaku marah terhadap siswa. Dari semua perilaku yang ditunjuk-kan guru tersebut dapat dianalisis bahwa guru di SMA N 2 Singaraja tidak hanya menjalankan tugas mengajarnya namun guru juga melakukan pengelolaan kelas. Serta guru terlihat terampil dan tahu apa yang baik yang harus dilakukan dalam mengelola kelas.

Selain itu dari hasil UNBK SMA N 2 Singaraja siswa SMA N 2 Singaraja yang mendapat pelajaran bahasa Jepang tidak ada yang memilih pelajaran bahasa Jepang sebagai salah satu pelajaran pilihan yang diujikan saat UNBK. Hal ini menunjukkan minat dan motivasi siswa kurang terhadap pelajaran bahasa Jepang atau pembelajaran bahasa Jepang di dalam kelas kurang optimal sehingga tidak ada siswa yang berminat memilih pelajaran bahasa Jepang sebagai mata pelajaran pilihan yang diujikan pada saat UNBK. Dari hasil wawancara yang dilakukan dengan siswa pada 7 Mei 2018 siswa menyampaikan bahwa pembelajaran bahasa Jepang itu sulit karena dalam pembelajaran dikelas saja siswa sulit memahami pembelajaran bahasa Jepang sehingga siswa merasa tidak percaya diri, tidak berminat untuk memilih pelajaran bahasa Jepang pada UNBK.

Dari apa yang telah dipaparkan, sebagai guru muda yang mengampu mata pelajaran bahasa Jepang di SMA N 2 Singaraja yang dihadapkan dengan berbagai karakter siswa dalam kelas, dan paradigma perubahan kurikulum. Guru SMA N 2 Singaraja tetap dapat mengelola kelas atau jalannya pembelajaran dengan cukup baik.

Penelitian ini hanya membahas mengenai pendekatan dalam pengelolaan kelas, prinsip-prinsip pengelolaan kelas, kom-ponen-komponen pengelolaan kelas dan penataan ruang kelas yang dilakukan oleh guru bahasa Jepang dalam pembelajaran bahasa Jepang di SMA Negeri 2 Singaraja.

Rumusan masalah dalam penelitian ini yaitu bagaimanakah pengelolaan kelas yang dilakukan oleh guru bahasa Jepang di SMA Negeri 2 Singaraja dalam pem-belajaran bahasa Jepang?

Berdasarkan rumusan masalah tersebut, tujuan penelitian ini adalah mendeskripsikan penge-lolaan kelas yang dilakukan oleh guru bahasa Jepang di SMA Negeri 2 Singaraja dalam pembelajaran bahasa Jepang.

\section{Metode}

Penelitian ini menggunakan rancangan penelitian deskriptif kualitatif yang akan dijadikan pedoman dalam melakukan penelitian. Penelitian deskriptif kua-litatif merupakan penelitian yang bertujuan untuk menggambarkan, meringkaskan berbagai kondisi, situasi, atau berbagai fenomena realitas sosial yang ada di masyarakat yang menjadi objek penelitian, dan berupaya menarik realitas itu ke permukaan sebagai suatu ciri, karakter, sifat, model, tanda, atau gambaran tentang kondisi, situasi, ataupun fenomena tertentu (Bungin, 2009:68). Rancangan penelitian deskriptif kualitatif digunakan karena data-data yang diperoleh dalam penelitian ini merupakan data dalam bentuk kata-kata, perilaku dan gambar yang akan dianalisis dengan meng-gunakan kata-kata/kalimat sebagai bentuk penggambaran terhadap keadaan objek/subjek penelitian.

Menurut Suharsaputra (2012: 207) pengumpulan data pada dasarnya merupakan serangkaian proses yang dilakukan sesuai dengan metode penelitian yang dipergunakan. Dalam melakukan penelitian metode yang digunakan adalah metode observasi, wawancara, dan dokumentasi untuk mengetahui bagaimana pengelolaan kelas dalam pembelajaran bahasa Jepang oleh guru SMA N 2 Singaraja.

Menurut Sugiyono (2014:333) dalam penelitian kualitatif, data diperoleh dari berbagai sumber dengan menggunakan teknik pengumpulan data yang bermacam-macam (triangulasi), dan dilakukan secara terus-menerus sampai datanya jenuh. Aktivitas dalam analisis data yaitu data reduction, data display, dan conclusion drawing/verification.

Data reduction atau rereduksi data berarti merangkum, memilih hal-hal yang pokok, memfokuskan pada hal-hal penting, dicari tema dan polanya. Dengan demikian data yang telah direduksi akan memberikan gambaran yang lebih jelas, dan mempermudah peneliti 
untuk melakukan pengumpulan data selanjutnya, serta mencarinya bila diperlukan (Sugiyono, 2009:247).

Setelah data direduksi, maka langkah selanjutnya adalah menyajikan data (data display). Penyajian data dilakukan untuk lebih menyistematiskan data yang telah direduksi sehingga terlihat sosoknya yang lebih utuh. Dalam penyajian data, laporan yang sudah direduksi dilihat kembali gambarannya secara keseluruhan, sehingga dapat ter-gambar konteks data secara keseluruhan, dan dari situ dapat dilakukan penggalian data kembali apabila dipandang perlu untuk lebih mendalami masalahnya (Suharsa putra, 2012:219).

Langkah selanjutnya dalam analisis data kualitatif adalah penarikan kesimpulan dan verifikasi. Kesimpulan awal yang dikemukakan masih bersifat sementara, dan akan berubah bila tidak ditemukan bukti-bukti yang kuat yang mendukung pada tahap pengumpulan data berikutnya. Tetapi apabila kesimpu-lan yang dikemukakan pada tahap awal didukung oleh bukti-bukti yang valid dan konsisten saat peneliti kembali ke lapangan mengumpulkan data, maka kesimpulan yang dikemukakan merupakan kesimpu-lan yang kredibel (Sugiyono, 2009:252).

Pada penelitian ini, uji kredibilitas dilakukan hanya sebatas menggunakan triangulasi teknik. Triangulasi teknik dilakukan dengan cara mengecek data dari sumber yang sama namun dengan cara yang berbeda. Dalam hal ini derajat kepercayaan dilakukan dengan cara mengecek data hasil observasi dengan data hasil wawancara dari sumber yang sama. Selain itu, derajat kepercayaan data dilakukan dengan menggunakan bahan referensi (Sugiyono, 2009:375). Yang dimaksud dengan bahan referensi adalah adanya pendukung untuk membuktikan data yang telah ditemukan peneliti. Dalam hal ini, bahan referensi dalam laporan penelitian dilengkapi dengan foto-foto agar dapat lebih dipercaya.

\section{Hasil dan Pembahasan}

Pada dasarnya dalam proses pembelajaran di kelas keterampilan guru merupakan salah satu faktor yang penting dalam menentukan keberhasilan peserta didik. Guru yang kompeten atau terampil akan lebih mampu menciptakan lingkungan belajar yang efektif. Keterampilan guru untuk men-ciptakan dan memelihara kondisi belajar yang optimal, positif, dan memfasilitasi kegiatan pembelajaran sesuai kebutuhan agar peserta didik dapat belajar secara efektif dan efisien akan membantu per-kembangan intelektual, emosional, dan sikap siswa guna mencapai tujuan pembelajaran. Salah satu cara yang dapat dilakukan oleh guru untuk mencapai hal tersebut adalah dengan keterampilan mengelola kelas. Pengelolaan kelas merupakan salah satu keterampilan dasar mengajar yang harus dikuasai oleh guru.

Guru bahasa Jepang di SMA N 2 Singaraja sudah melakukan pengelolaan kelas dalam pem-belajaran bahasa Jepang. Secara umum pengelolaan kelas dilakukan oleh guru untuk menciptakan dan memelihara kondisi belajar yang optimal, efektif dan tidak terjadi gangguan selama proses pem-belajaran. Berbagai upaya dilakukan oleh guru dalam mengelola kelas baik yang bertujuan untuk menciptakan, memelihara kondisi belajar ataupun untuk mencegah gangguan yang timbul ketika pembelajaran, sehingga tujuan pembelajaran dapat tercapai. Hal ini sejalan dengan pendapat Suryani \& Agung (2012:184) menyatakan pengelolaan kelas adalah keteram-pilan guru untuk menciptakan dan memelihara kondisi belajar yang optimal dan mengembalikanya bila terjadi gangguan dalam proses belajar mengajar.

Berdasarkan hasil wawancara yang telah dilakukan dengan guru, pengelolaan kelas dilakukan untuk menangani dan menekan perilaku siswa yang nakal atau yang sering menimbulkan masalah di dalam kelas. Sehingga siswa akan dapat lebih memerhatikan pembelajaran, dapat mendengar penjelasan guru dengan lebih jelas, belajar dengan santai, siswa menjadi lebih disiplin, dan pembelajaran dapat berjalan dengan lancar sesuai yang diharapkan. Guru juga menyampai-kan bahwa tidak dipungkiri masih ada saja siswa yang menimbulkan kegaduhan ketika pembelajaran. Namun hal itu tidak menjadi masalah selama guru bisa mengendalikan situasi dalam kelas dan selama siswa masih mau memerhatikan pembelajaran sesuai harapan guru, tingkah laku siswa dapat dimaklumi dan diarahkan.

Guru di SMA 2 Singaraja menggunakan berbagai macam pendekatan pengelolaan kelas dalam menghadapi berbagai situasi saat pembelajaran berlangsung. Berdasarkan 
hasil observasi dan wawancara yang telah dilakukan, pendekatan dalam pengelolaan kelas yang diterapkan oleh guru adalah pendekatan kekuasaan, pendekatan ancaman, pendekatan kebebasan, pendekatan pengajaran, pendekatan perubahan tingkah laku, pendekatan suasana emosi dan hubungan sosial, pendekatan proses kelompok, dan pendekatan elektis atau pluralistik. Pendekatan tersebut dilakukan guru dalam berbagai situasi dalam kelas untuk menciptakan atau mempertahankan kondisi pembelajaran agar berjalan dengan kondusif, efektif, efisien dan tidak terjadi gangguan selama pembelajaran.

Dari berbagai pendekatan yang dilakukan guru dalam mereaksi berbagai situasi dalam kelas, pendekatan resep (Cook Book) tidak dilakukan oleh guru. Pendekatan resep adalah pendekatan yang memberikan suatu daftar yang dapat menggambarkan apa yang harus dan apa yang tidak boleh dikerjakan oleh guru dalam mereaksi semua masalah atau situasi yang terjadi dikelas. Berdasarkan hasil observasi guru di SMA N 2 Singaraja tidak terlihat memberikan suatu daftar yang menggambarkan apa yang boleh dan apa yang tidak boleh dilakukan guru dalam mereaksi masalah atau situasi dalam kelas. Dari hasil wawancara guru menyampaikan bahwa guru tidak menyiapkan suatu daftar khusus untuk mereaksi situasi dalam kelas seperti yang sudah dijelaskan. Menurut guru situasi dan kondisi pembelajaran setiap pertemuan tidak menentu. Jadi untuk mereaksi semua masalah atau situasi yang terjadi dalam kelas, respon ataupun tindakan yang diambil oleh guru disesuaikan dengan apa yang terjadi dalam kelas.

Selama ada usaha dari guru, gangguan di kelas pasti dapat diatasi. Dalam rangka memperkecil masalah gangguan dalam pengelolaan kelas, prinsip-prinsip pengelolaan kelas juga dapat digunakan. Prinsip-prinsip penge-lolaan kelas yang digunakan oleh guru SMA N 2 singaraja dalam pembelajaran bahasa Jepang adalah hangat dan antusias, tantangan, bervariasi, dan penanaman disiplin diri.

Guru juga mengunakan atau menerapkan komponen-komponen keterampilan pengelolaan kelas dalam mengelola kelas saat proses pembelajaran berlangsung. Menurut Djamarah (2006:186) komponen-komponen keterampilan pengelolaan kelas pada umumnya dibagi menjadi dua bagian, yaitu keterampilan yang berhubungan dengan penciptaan dan pemeliharaan kondisi belajar yang optimal dan keterampilan yang berhubungan dengan pengem-bangan kondisi belajar yang optimal. Keterampilan yang berhubungan dengan penciptaan dan pemeliha-raan kondisi belajar yang optimal dilakukan guru dengan mengambil inisiatif dan mengendalikan pelaja-ran serta aktivitas-aktivitas pem-belajaran yang berkaitan dengan sikap tanggap, membagi perhatian, dan pemusatan perhatian kelompok. Kemudian keterampilan yang berhubungan dengan pengem-bangan kondisi belajar yang optimal yaitu keterampilan yang berkaitan dengan tanggapan guru terhadap gangguan anak didik yang berkelanjutan, dengan maksud agar guru dapat mengadakan tindakan remidial untuk mengembalikan kondisi belajar yang optimal. Guru pada tingkat tertentu dapat menggunakan seperangkat strategi untuk tindakan perbaikan terhadap tingkah laku anak didik yang terus-menerus menimbulkan gangguan dan yang tidak mau terlibat dalam tugas kelas dalam rangka pengembangan kondisi belajar yang optimal. Strategi yang digunakan guru SMA N 2 Singaraja adalah modifikasi tingkah laku dan pendekatan pemecahan masalah kelompok. Sedangkan strategi menemukan dan memecahkan tingkah laku yang menimbulkan masalah tidak dilakukan oleh guru dalam mengelola kelas.

Dalam mengelola kelas, agar tercipta suasana belajar yang menggairahkan, perlu diperhatikan pengaturan/penataan ruang kelas/belajar (Djamarah, 2006:204). Penyusunan dan pengaturan ruang belajar hendaknya memungkinkan anak duduk berkelompok dan memudahkan guru bergerak secara leluasa untuk membantu siswa dalam belajar. Berdasarkan hasil observasi dan wawancara yang telah dilakukan, penataan ruang kelas dilakukan dengan pengaturan tempat duduk siswa berbaris berjejer kebelakang. Pengaturan alat-alat pengajaran berupa LCD proyektor, papan tulis, penghapus papan tulis, spidol dan penataan keindahan dan kebersihan kelas berupa jam dinding, foto presiden, foto wakil presiden, gambar burung garuda, gambar pahlawan, pas bunga, taplak meja, lemari, jadwal piket kelas, lampu kelas, jendela dan ventilasi udara diatur oleh sekolah dan disesuaikan 
dengan aturan sekolah. Namun guru dan siswa dapat melakukan penataan kelas sesuai kebutuhan ketika proses pembelajaran dan/atau atas seijin dari sekolah.

\section{Simpulan dan Saran}

KESIMPULAN

Kesimpulan yang dapat diambil dari penelitian ini adalah guru bahasa Jepang di SMA $\mathrm{N} 2$ Singaraja melakukan pengelolaan kelas dalam pembelajaran bahasa Jepang dengan menggunakan berbagai pendekatan pengelolaan kelas. Pendekatan yang digunakan adalah pendekatan kekuasaan, pendekatan ancaman, pendekatan kebebasan, pendekatan pengajaran, pendekatan perubahan tingkah laku, pendekatan suasana emosi dan hubungan sosial, serta pendekatan elektis atau pluralistik.

Komponen keterampilan pengelolaan kelas yang berhubungan dengan penciptaan dan pemeliharaan kondisi belajar yang optimal dilakukan guru dengan cara menunjukkan sikap tanggap seperti melakukan kontak pandang dan gerak mendekati individu atau kelompok siswa. Dengan cara membagi perhatian saat pembelajaran dan dengan cara melakukan pemusatan perhatian kelompok ketika siswa belajar secara berkelompok. Kemudian komponen keterampilan pengelolaan kelas yang berhubungan dengan pengembangan kondisi belajar yang optimal dilakukan guru dengan cara melakukan pendekatan pemecahan masalah kelompok, memelihara serta memulihkan semangat siswa dalam bekerjasama dengan kelompok, dan dengan cara modifikasi tingkah laku.

Penataan ruang kelas dalam rangka pengelolaan kelas yaitu berupa pengaturan tempat duduk siswa yang berbaris berjejer ke belakang, pengaturan alat-alat pengajaran berupa LCD proyektor, papan tulis, penghapus papan tulis, dan spidol. Penataan keindahan dan kebersihan kelas berupa jam dinding, foto presiden, foto wakil presiden, gambar burung garuda, gambar pahlawan, pas bunga, taplak meja, lemari kelas, dan jadwal piket kelas. Serta penataan lampu kelas, jendela, dan ventilasi udara diatur oleh sekolah dan disesuaikan dengan aturan sekolah. Namun guru dan siswa dapat melakukan penataan kelas sesuai kebutuhan ketika proses pembelajaran dan/atau atas seijin dari sekolah.

\section{SARAN}

Guru sebaiknya menguasai keterampilan mengelola kelas agar dapat mengelola segala aspek pendidikan pengajaran menjadi sebuah aktivitas belajar bersama dan agar pembelajaran berjalan dengan efektif, efisien, dan kondusif sehingga terjadi perkembangan intelektual, emosional, dan sikap peserta didik. Serta agar tujuan pembelajaran dapat tercapai. Penataan ruang kelas sebaiknya ditujukan untuk keperluan belajar dan disesuaikan dengan kebutuhan pembelajaran. Segala keperluan belajar di dalam kelas seperti tempat duduk, alat-alat dan media pengajaran, serta penataan keindahan dan kebersihan kelas diperuntukan untuk kenyamanan siswa dalam belajar dan untuk kepentingan serta kemudahan dalam proses belajar mengajar.

\section{Daftar Pustaka}

Arikunto, Suharsimi. 1993. Manajemen Pengajaran Secara Manusiawi. Jakarta: PT Rineka Cipta.

Sugiyono. 2009. Metode Penelitian Kuantitatif, Kualitatif dan R\&D. Cetakan ke-7. Bandung: CV.Alfabeta.

Sugiyono. 2014. Metode Penelitian Pendidikan.Cetakan ke-20. Bandung: CV.Alfabeta.

Bungin, Burhan. 2009. Penelitian Kualitatif Komunikasi, Ekonomi, Kebijakan Publik, dan IImu Sosial lainnya. Cetakan ke-3. Jakarta: Kencana Prenada Media Group.

Barnawi \& Mohammad Arifin. 2012. Etika dan Profesi Kependiikan. Jogjakarta: AR-Ruzz Media.

Djamarah, Syaiful Bahri dan Aswan Zain. 2006. Strategi Belajar Mengajar. Jakarta: PT Rineka Cipta. 
Fathurrohman, Pupuh dan Sobry Sutikno. 2011. Strategi Belajar Mengajar: Strategi Mewujudkan Pembelajaran Bermakna Melalui Penanaman Konsep Umum \& Islami. Bandung: PT Refika Aditama.

Mardhiah, Eliwatis., dan Khaira, K. 2014. "Pelaksanaan Pengelolaan Kelas oleh Guru Biologi dalam Menciptakan dan Memelihara Kondisi Belajar yang Optimal". Jurnal Pembelajaran MIPA STAIN Batusangkar Volume satu tahun 2014. Tersedia pada http://id.portalgaruda.org/?ref=browse\&mod=viewarticle\&article=250901 (diakses pada tanggal 19 September 2016).

Permendiknas RI No. 16. 2007. Standar Kualifikasi Akademik dan Kompetensi Guru. Jakarta: Departemen Pendidikan Nasional.

Suharsaputra, Uhar. 2012. Metode Penelitian Kuantitatif, Kualitatif, dan Tindakan. Cetakan pertama. Bandung: PT Refika Aditama.

Surjana, A. 2002. "Efektivitas Pengelolaan Kelas". Jurnal pendidikan penaburan 1. Terdapat pada https://scholar.google.co.id/scholar?hl=id\&q =jurnal +guru+ tentang+ pengelolaan + kelas \&btnG $=$ (diakses pada tanggal 19 September 2016).

Suryani, Nunuk dan Leo Agung. $\quad$ 2012. Strategi Belajar Mengajar. Yogyakarta: Penerbit Ombak.

Ulandari, Nyoman Sri. 2015. "Pengelolaan Kelas Guru Bahasa Jepang Di SMA 1 Sukasada". Skripsi (tidak diterbitkan). Program Studi Pendidikan Bahasa Jepang Fakultas Bahasa Dan Seni, Univeritas Pendidikan Ganesha Singaraja. 